\title{
Relationship Between Crude Oil Prices and Terms Of Trade In Oil Exporting Countries: A Comparison Between Nigeria and Angola
}

Akomolafe Kehinde John*, Onwuso Precious

AfeBabalola University, Ado Ekiti.

\section{Abstract}

\begin{abstract}
In the face of fluctuation in oil price in the world today, it has become imperative that its effects on various economies are known. The study is a comparative study of the effects of crude oil price change on terms of trade in Nigeria and Angola from 1981 to 2017. OLS estimation technique was used for the analysis. The results indicate that positive change in oil price leads to increase in term of trade in both countries. This means that an increase in oil price leads to improvement in term of trade of each country. The result is however minute, meaning that for oil price to have much effects on term of trade of the two countries, the change must be of great magnitude. This study recommends that there is a need to diversify the export base of each country to reduce reliance on oil. This will help reduce the vulnerability of the countries' term of trade to shock in oil price.
\end{abstract}

Keywords: Nigeria; Angola; Crude Oil Price; Term Of Trade; OLS.

\section{Introduction}

A country's term of trade plays important role in the country's dealing with the outside world. This is because it determines the gains that accrue to a country from trade. If term of trade moves in a country's favour, it will increase a country's gain from trade, and consequently leads to more growth, and more standard of living. One factor that determines a country's term of trade is her export and import prices. An increase in the export prices of a country tend to increase her term of trade, while an increase in the import price has opposite effects.

In oil exporting countries such as Nigeria and Angola, movement in crude oil has impacts on the export values, and consequently, on the term of trade. For countries that depend heavily on oil exports, a rise in oil price may mean increase in revenue, increase in foreign earnings, appreciation of exchange rate, etc. It could also lead to increase in corruption, neglect of other sectors etc, if not properly managed. This is the experience in most developing countries which depend heavily on oil exports. A decrease in oil price would have reverse effects for oil exporting countries.

For oil importing countries, a rise in oil price may lead to increase in domestic pump price of oil, increase in price level, decrease in real wage, increase in unemployment, deteriorating exchange rate, increased in input costs, and a deteriorating term of trade. However, a decrease in crude oil price could lead to a decrease in domestic pump price of PMS, a reduced general price level, appreciated exchange rate, and improved term of trade. Overall, the effect of change in oil price on a country depends on the extent to which she depends on oil export or imports, and the availability of alternative fuel.

The term of trade is the term at which two countries trade with each other. It is the rate at which a country exchanges her export for her imports. The term of trade is the determinant of the gains of a country in international trade. Increase in crude oil price leads to improvement in term of trade, but a decrease in oil price leads to deterioration of term of trade. Increase in term of trade will mean increase in income for oil exporting countries,

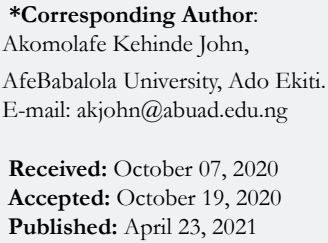

Citation: Akomolafe, Kehinde John, Onwuso Precious. Relationship Between Crude Oil Prices and Terms Of Trade In Oil Exporting Countries: A Comparison Between Nigeria and Angola. Int J Financ Econ Trade. 2021;4(01):74-83. doi: http://dx.doi.org/10.19070/2643-038X-190010

Copyright: Akomolafe ${ }^{\circ}$ 2021. This is an open-access article distributed under the terms of the Creative Commons Attribution License, which permits unrestricted use, distribution and reproduction in any medium, provided the original author and source are credited. 
while a decrease in term of trade will mean a decrease in income for oil importing countries.

The position of developing nations in the world economy has always been a subject of concern. This is because developing countries trade in primary products that command little prices in international market. This has made their terms of trade deteriorate, except for some oil exporting countries who enjoyed high terms of trade because of rise in crude oil price.

However, the recent experience in the oil market is a thing of concerns for oil exporting countries, especially in Africa. According to [13], there was an average $50 \%$ fall in crude oil prices between June 2014 and January 2015. From \$110 a barrel of Brent oil in June 2014, it fell to $\$ 80$ before late November, 2014, and by January, 2015, it was $\$ 50$ a barrel. The fall continued till the end of 2015 as the year closed at $\$ 37.19$ a barrel. At the start of 2016, it fell further to $\$ 31.68$ per barrel, and by the second month of 2016, crude oil price traded at $\$ 26$ for each barrel. It picked up marginally to $\$ 51$ at the end of 2016. In 2017, the world oil market continues to experience instability as the average oil price has been hovering around $\$ 50[10]$.

This has had various effects on many developing countries, especially the oil exporting ones. According to African Development Bank [1], the oil effect on African countries has been negative. This is especially for oil-exporting countries. For instance, the average inflation in 2016 was 29.1\% in Angola, 17.9\% in Sudan, $17.8 \%$ in Ghana, and $15.3 \%$ in Nigeria. The cumulative average GDP growth rate in oil-exporting countries in Africa fell from $3.7 \%$ in 2014 to $1.1 \%$ in 2016. In similar vein, average GDP growth rate in oil-importing countries fell from 3.8\% in 2014 to $3.6 \%$ in 2015, and 3\% in 2016. Though both oil-and oil-exporting countries were affected by the fall in the oil price, it is more felt by oil-exporting countries.

In Nigeria, oil exports constitute a large portion of the country's export earnings, accounting for over $90 \%$ of the country's export earnings in 2015 [7]. This indicates that any shock in international crude oil market will have a bearing on the country's economy. The fall in crude oil price between 2014 and 2016 and its effects on the economy is a testament to this. The country's external reserve fell from $\$ 47,903.1$ million in April, 2013 to $\$ 23,806.5$ million in September, 2016. This put pressure on exchange rate to depreciate to N462 to a dollar in October, 2016 from N163 to a dollar in September, 2013 [8]. Similarly, there was a rise in inflation rate from $8.5 \%$ in December, 2013 to $15.7 \%$ in the same period in 2016. Similarly, government revenue fell from N7, 752.20 Billion in 2013 to N3,955.70 billion in 2016. The country's current account also decreased from a surplus balance of $\$ 19,205.1$ million in 2013 to a deficit of $\$ 15,438.6$ in 2015 (CBN, 2017). This consequently had its effects on the country's term of trade. Nigeria's term of trade fell from 152 in 2013 to 101 in 2016 [22].

In Angola, crude oil exports represents the main stay of the country's economy. According to UNCTAD (2016), crude oil exports accounted for about $96 \%$ of the country's total exports. Similarly, $80 \%$ of the country's total revenue was from crude oil exports. This shows the extent of the country's dependence on the oil sector. The over dependence on the sector, has no doubt, affected exports from other sectors of the economy. This invariably implies that the country is susceptible to the events in the world oil markets. Hence, with the fall in crude oil price, exchange rate depreciated from 93.9 kwanza to one U.S. dollar in 2011 to 166.7 kwanza in 2016 [20]. The country's current account which was in surplus of $\$ 13.841$ billion US dollars in 2012 fell to deficit of $\$ 10.273$ billion in 2015 in 2015 as a result of the fall in the values of exports. Similarly, inflation increased from a single digit of an average of 8.78 per cent between 2012 and 2014 to $42 \%$ by the end of 2016. The overall implication of this was the revision of the country's growth projection from 7.5 per cent in 2012 to 1.1 per cent in 20162017 [2]. The country's term of fell from 105 in 2013 to 48 in 2016 [22].

An increase in oil price is a blessing to oil exporting countries, but a disadvantage to oil importing ones. The effect on countries that are both oil importer and exporter is however indeterminate. Nigeria and Angola are both crude oil exporters, at the same time, they are both refined oil importers. This study therefore examines the effect of change in crude oil price on terms of trade of both countries. Understanding this is imperative for policy makers in oil exporting countries tofind a way to better position the countries term of trade so as to avoid such future occurrences. The two countries were chosen based on the fact they are the two largest oil exporters in Africa. Also, they rely heavily on crude oil exports for their exports earnings, and they import major proportion of their refined oil. However, while Nigeria is in West Africa, Angola is in Central Africa.

\section{A Look At Some Stylized Facts}

\section{Change In Oil Price (2013 to 2016)}

As shown in Figure 1, the Brent crude oil price in first quarter of 2013 was $\$ 94.33$. This increased marginally to $\$ 105.83$ in at the end of the third quarter of 2013 , and fell again to $\$ 97.5$ at the end the fourth quarter of 2013. In 2014, oil price bounced back to $\$ 103.35$ at the end of the second quarter. At the end of the fourth quarter of 2014 , oil price fell to $\$ 73.21$. It continued falling in 2915 and closed at the end of the year at $\$ 41.94$. It also fell to $\$ 33.35$ at the beginning of 2016 and improved marginally at the third quarter of 2016 to $\$ 49$.

Source: Federal Reserve Bank of St. Louis database [10]

\section{Angola GDP Growth and Oil Price (2009 - 2016)}

Figure 2 depicts the movement in oil price and GDP growth rate of Angola between 2009 and 2016. It shows that oil price and GDP growth rate follow similar pattern. As oil price increases in year 2009, reaching the pick of over $\$ 115$ in 2011, and GDP growth rate also increased in 2011. Afterwards, oil price fell, in 2012, and bounced back temporarily in 2013, but continued to fall afterwards, reaching as lowest level at $\$ 33$ in 2016. Similarly, GDP growth rate fell during the same and became negative in 2016.

Source: Federal Reserve Bank of St. Louis database [10] and World Bank Development Indicator [22]

\section{Nigeria GDP Growth and Oil Price (2009 - 2016)}

A similar situation exists in Nigeria as shown in Figure 3. The GDP growth rate movement shows the dependence of the coun- 
try's GDP on oil sector. The percentage fall in the oil price between 2014 and 2016 is about 50\%. GDP growths within the same period also fell by over $50 \%$. The GDP growth rate became negative in 2016. This shows the importance of crude oilprice in Nigerian economy. It shows that the economy is highly dependent on the development in the oil market.

Source: Federal Reserve Bank of St. Louis database [10] and World Bank Development Indicator [22].
Angola Government Revenue As Percentage Of GDP and Oil Price (2009 - 2016)

Figure 4 shows the movement in oil price and revenue as percentage of GDP in Angola between 2009 and 2016. It can be observed that Angola's revenue as percentage of GDP followed the trend as oil price movements, showing that it is influenced by movement in crude oil price throughout the periods.

Figure 1. Change in Barrel Oil Price.

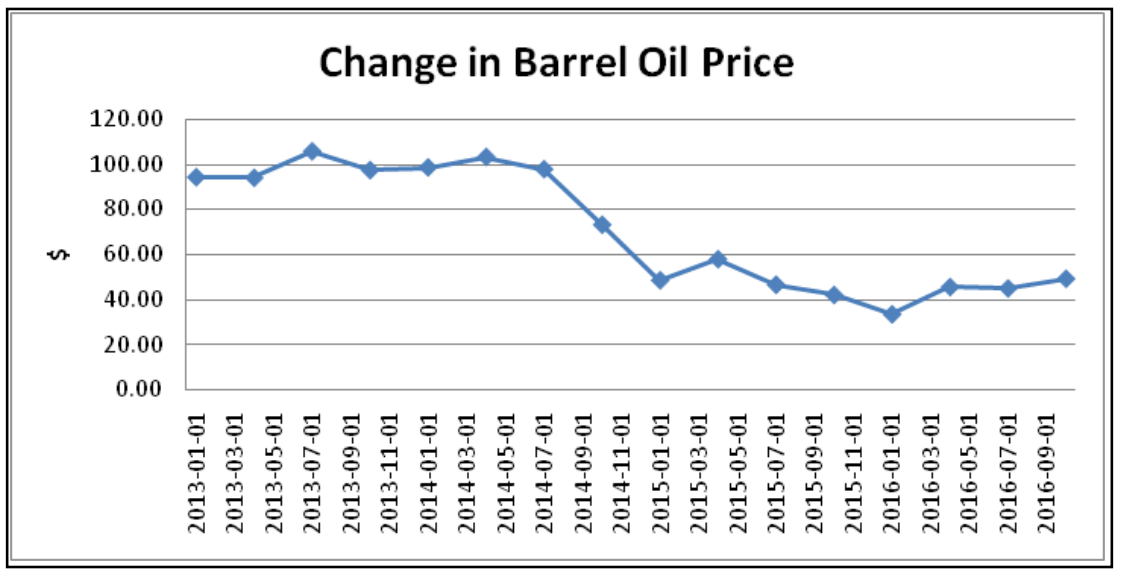

Figure 2. Movement in GDP Growth Rate and Oil Price in Angola.

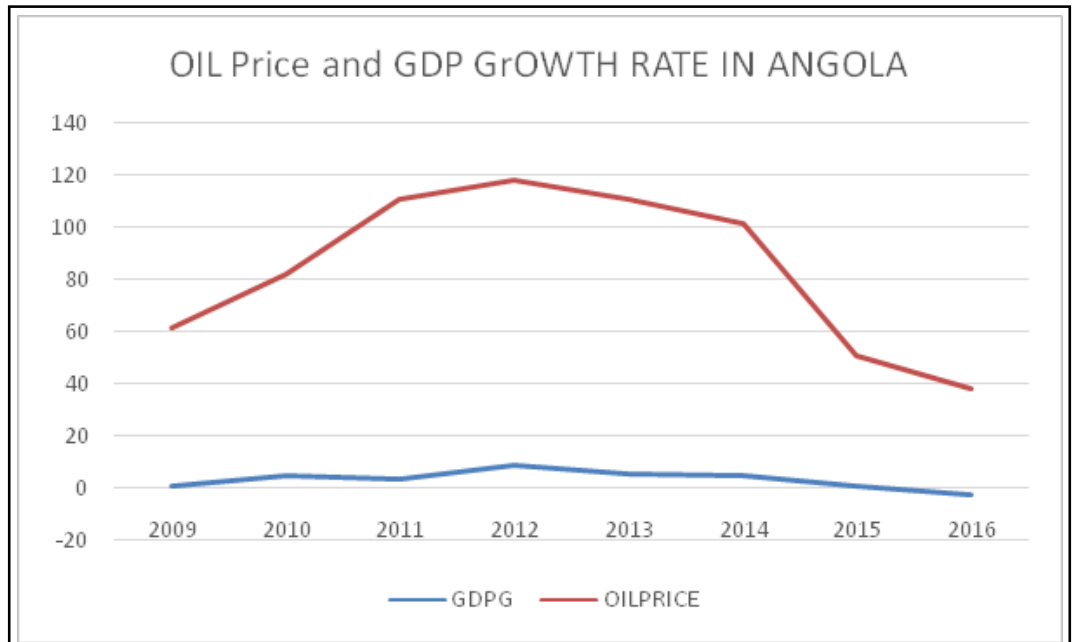

Figure 3. Nigeria GDP growth and Oil Price (2009-2016).

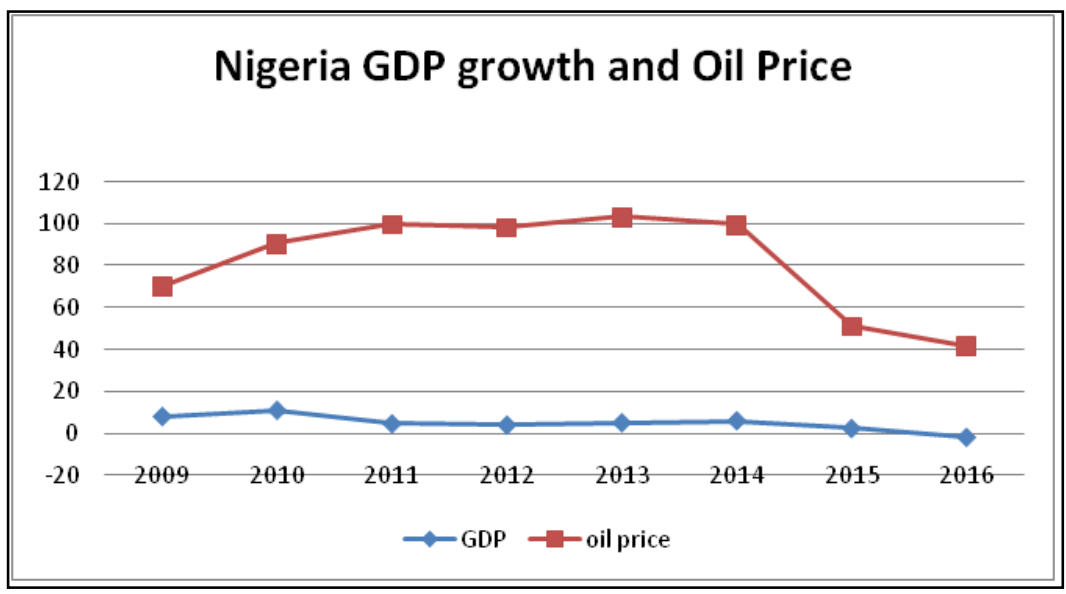


Source: Federal Reserve Bank of St. Louis database [10] and World Bank Development Indicator [22].

\section{Nigeria Government Revenue As Percentage Of GDP and} Oil Price (2009 - 2016)

As shown in Figure 5, there is a rise in revenue of government as percentage of GDP between 2009 and 2011. This correlates to the periods when oil price increased from $\$ 61.9$ to $\$ 94$. Beyond 2011, the revenue experienced a downswing. This also correlates to the period when oil price fell to an average of $\$ 43$ in 2016. This makes the Nigerian economy to be highly vulnerable to the happenings in the oil market.

Source: Federal Reserve Bank of St. Louis database [10] and World Bank Development Indicator [22].

\section{Angola Term Of Trade and Oil Price}

Figure 6 shows that there is a relationship between movement in term of trade and oil price in Angola. Oil price increased in 2009 through 2011. Similarly, term of trade increased during the same periods. Beyond 2011, term of trade began to fall as oil price also fell. Between 2011 and 2015. Oil price continued to fall. Similarly, term of trade fell, but the rate of the fall in term of trade is higher than that of crude oil price. This shows the extent to which the country depends on the oil sector.

Source: Federal Reserve Bank of St. Louis database [10] and World Bank Development Indicator [22].

\section{Nigeria Term Of Trade and Crude Oil Price Movements}

Figure 7 shows the relationship between term of trade and oil price movement in Nigeria. As expected, oil price and term of trade move in the same direction. As oil rice increased between 2009 and 2011. Between 2011 through 2014, oil price remained stable, but decreased afterwards. Similarly, term of trade increased between 2009 and 2011. From 2011 through 2014, it was relatively stable, but decreased afterwards.

Source: Federal Reserve Bank of St. Louis database [10] and World Bank Development Indicator [22].

Both Figures 6 and 7 shows that there is a relationship between movement in term of trade and crude oil price in the two countries. However, Angola has a higher term of trade than Nigeria does. The reason for this may be because non-oil export is higher in Angola than in Nigeria during the periods.

Figure 4. Angola Government Revenue as Percentage of GDP and Oil Price (2009-2016).

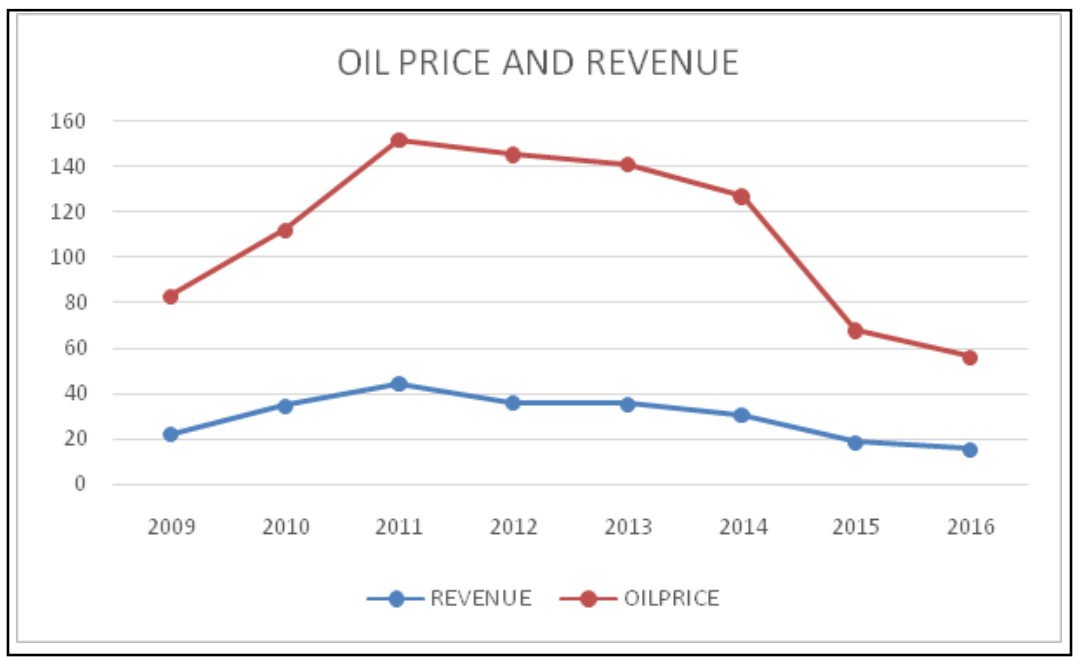

Figure 5. Nigeria Government Revenue as Percentage of GDP and Oil Price (2009 - 2016).

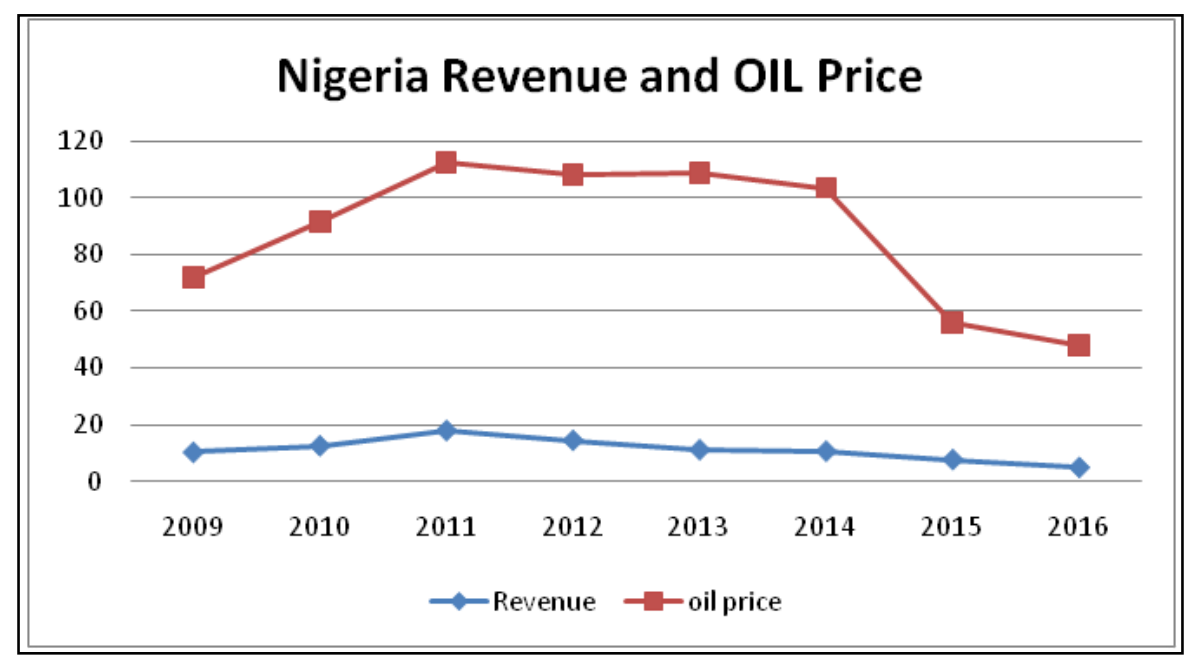


Figure 6. Angola Term of Trade and Crude Oil Price Movements.

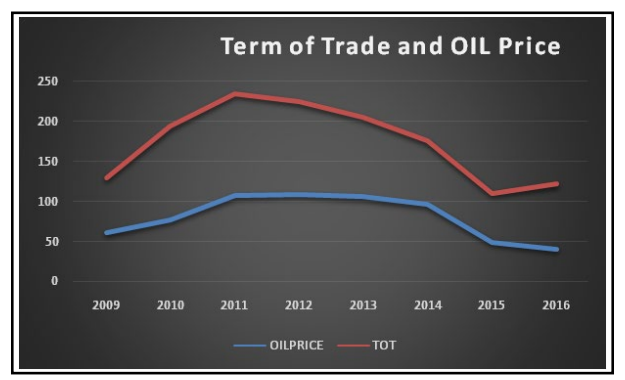

Figure 7. Nigeria Term of Trade and OIL Price.

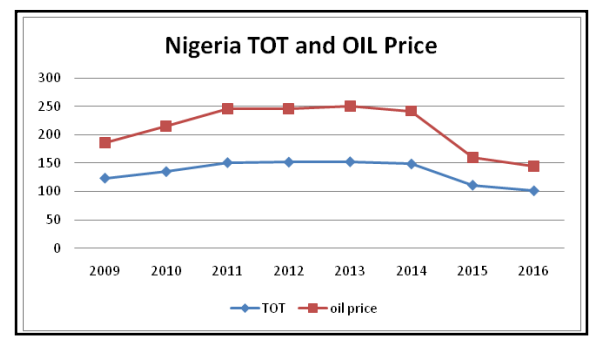

\section{Review Of Some Related Empirical Literature}

There have been various attempts to examine the relationship between oil price and term of trade in the literature. For instance, some $[11,17,6,4,21,5,16,12]$ examined the effects of term of trade changes on economic activities. Fosu [11] examined the influence of change in barter term of trade on economic growth in Botswana and Nigeria using Autoregressive Distributed Lag (ARDL) approach. The result shows that TOT had a positive effect on economic growth of Botswana, but a negative effect on economic growth of Nigeria. He concluded that the reason for the difference in the results is because Botswana had a superior institutional quality than Nigeria. Also, Mendoza [17] examined the effect of terms-of-trade uncertainty on savings and growth in some selected developing countries. He found out that increased terms-of-trade fluctuation leads to a reduction in social welfare, but could lead to faster or slower growth depending on the degree of risk aversion of the country. Bleaney and Greenaway [6] examined the impact of terms of trade and real exchange rate volatility on investment and growth in fourteen sub-Saharan 0 African countries between 1980 and 1995. The panel result shows that term of trade instability had a negative effect on economic growth.

In a similar study, Blattman, Hwang, and Williamson [4] examined the relationship between terms of trade and economic growth in some selected countries from 1870 to 1983 . They divided the countries in to core and periphery countries, based on their share of primary products in their exports; level of development; and similar sample sizes. The result shows asymmetric effects between term of trade and economic growth in both the core and periphery countries. Wong [21] investigated the relationship between terms of trade and economic growth in Japan and Korea. He found out that an increase in terms of trade volatility leads to a decrease in real GDP per capita, but the effects were different between the two countries. Grimes [12] examined the relationship between term of trade and economic growth in New Zealand. The result shows a positive relationship between term of trade and economic growth. Also, Jawaid, and Waheed [16] examine the effects of terms of trade and its volatility one economic growth in some selected 94 developed and developing countries from 2004 to 2008. The result shows that TOT had positive and significant effects on economic growth.

Others like $[3,9,18]$ examined the relationship between oil price and term of trade. Using a dynamic general equilibrium model, Backus and Crucini [3] found out that change in oil price accounts for much of the variation in the terms of trade in the countries examined. Also, Dibooğlu and Aleisa [9] found out that oil price variation affected term of trade shock in Saudi Arabia, and conclude that the country needs to diversify its production base in order to stabilize output and the real exchange rate. Mirfacihi [18] compared the effects of change in oil price on term of trade between USA and Saudi Arabia from 1970 to 2004. The result shows that that oil price had a negative effect on term of trade of the net importing country, but its effect on term of trade of oil exporting country is not clear. In all, literature on the effects of change in oil price on term of trade is still scanty, especially in Nigeria and Angola. This study therefore fills this gap in the literature.

\section{The Method}

In this section, the method used to achieve the aim of this paper is discussed. It consists of the models used, description of the variables, data type, and the estimation technique.

\section{Specifying The Model}

Following the specification used by Mirfacihi [18], the model is specified as follows:

$\mathrm{TOT}=\mathrm{f}(\mathrm{OILPCHA}$, INFLATI, GDPGR).

The empirical model is presented in equation 1

TOT $_{t}-t=\delta_{0}+\delta_{1}$ OILPCHA $_{t}+\delta_{2}$ INFLATI $_{t}+\delta_{3}$ GDPGR $_{t}+$ $\varepsilon_{\mathrm{t}} \ldots \ldots \ldots \ldots \ldots \ldots \ldots(2)$

Where TOT is the term of trade in a given year t. OILPCHA 
Table 1. ADF Unit Root Test Results.

\begin{tabular}{|c|c|c|c|c|}
\hline Variables & Test for Unit Root & Intercepts & Prob & Remarks \\
\hline TOT & Level & $-3.285172^{* *}$ & 0.0231 & $\mathrm{I}(0)$ \\
\hline OILPCHA & Level & $-5.653270^{* * *}$ & 0.0000 & $\mathrm{I}(0)$ \\
\hline GDPGR & Level & $-4.045483^{* * *}$ & 0.0034 & $\mathrm{I}(0)$ \\
\hline INFLATION & Level & $-13.33666^{* * *}$ & 0.0000 & $\mathrm{I}(0)$ \\
\hline \multicolumn{5}{|c|}{ Critical Value } \\
\hline
\end{tabular}

Table 2. KPSS Unit Root Test Results.

\begin{tabular}{|c|c|c|c|}
\hline Variables & Test for Unit Root & Intercepts & Remarks \\
\hline TOT & Level & $0.283374^{* * *}$ & $\mathrm{I}(0)$ \\
\hline OILPCHA & Level & $0.201491^{* * *}$ & $\mathrm{I}(0)$ \\
\hline GDPGR & Level & $0.405867^{* * *}$ & $\mathrm{I}(0)$ \\
\hline INFLATION & Level & $0.457763^{* * *}$ & $\mathrm{I}(0)$ \\
\hline \multicolumn{4}{|c|}{ Critical Value } \\
\hline \\
\hline & $1 \%$ & 0.739000 & \\
\hline & $5 \%$ & 0.463000 & \\
\hline & $10 \%$ & 0.347000 & \\
\hline
\end{tabular}

indicates stationary at $1 \%$, **indicates stationary at $5 \%$ indicates stationary at $10 \%$.

Table 3. ADF Unit Root Test Results.

\begin{tabular}{|c|c|c|c|c|}
\hline Variables & Test for Unit Root & Intercepts & Prob & Remarks \\
\hline TOT & Level & $-3.120065^{* *}$ & 0.0339 & $\mathrm{I}(0)$ \\
\hline OILPCHA & Level & $-5.653270^{* * *}$ & 0.0000 & $\mathrm{I}(0)$ \\
\hline GDPGR & Level & $-3.545987^{* *}$ & 0.0122 & $\mathrm{I}(0)$ \\
\hline INFLATION & Level & $-3.740122^{* * *}$ & 0.0075 & $\mathrm{I}(0)$ \\
\hline \multicolumn{5}{|c|}{ Critical Value } \\
\hline \\
\hline
\end{tabular}

is the change in crude oil price, INFLATI is inflation rate, GDPGR is the growth rate of GDP. The model was used to examine the effects of change in crude oil price on term of trade in both countries.

\section{Explanation Of The Variables}

\section{Term Of Trade}

TOT data was be constructed in line with Mendoza (1995) as the ratio of export value index $(2000=100)$ to import value index $(2000=100)$. The data were sourced from World Bank Development Indicators database.

\section{Crude Oil Price Change}

The crude oil price was sourced from Federal Reserve Bank of St.
Louis database. Crude oil price change was calculated as the percentage change in crude oil price between one year and another. It was calculated as OILPCHA $=\mathrm{OILP}_{\mathrm{t}}-\mathrm{OILP}_{\mathrm{t}-1} / \mathrm{OILP}_{\mathrm{t}-1} * 100$

\section{Gross Domestic Product Growth Rate}

GDP was used as proxy for domestic market. An increase in domestic market was measured as growth of GDP. It was measured as $\mathrm{GDPGR}=\mathrm{GDP}_{\mathrm{t}}-\mathrm{GDP}_{\mathrm{t}-1} / \mathrm{GDPP}_{\mathrm{t}-1} * 100$. It was sourced from World Bank Development Indicators database.

\section{Inflation}

The inflation rate variable was measured as the change in GDP deflator annual percentage change. It was sourced from World Bank database. 


\section{Estimation Technique}

The variables were first tested for the presence of unit root using ADF and KPSS unit root tests. The ADF unit root test is based on the null hypothesis that says that the series contain unit root. The significance of the t-statistics is used to confirm the rejection of the null hypothesis, indicating that the variable does not contain unit root. A similar way of confirming or rejecting the null hypothesis is the use of the critical values. The values of the t-statistics is compared with the critical values. If the values of the $\mathrm{t}$-statistics is less than the critical values (Not the absolute values), the null hypothesis is rejected, while the alternative hypothesis is considered.

In the case of KPSS, the null hypothesis is that variable does not contain unit root. The rejection of the null hypothesis is based on the values of the LM statistics and the asymptotic critical values. If the values of the LM statistics is less than the asymptotic critical values the null hypothesis is not rejected.
The results of the unit root tests is instrumental in deciding the channel of the analysis. If the unit root indicates that the series have unit root, then a long run relationship is tested to using Cointegration technique. However, if all the series are void of unit root, the appropriate method of analysis Ordinary Least Square (OLS). Given the results of the unit root test, OLS was used for the estimation.

\section{Data Type and Source}

Annual data from 1981 to 2017 will be used in this study. They were sourced from World Bank database and Federal Reserve Bank of St. Louis database.

\section{The Results}

\section{Unit Root Test}

The first step in any time series analysis is to examine the time se-

Table 4. KPSS Unit Root Test Results.

\begin{tabular}{|c|c|c|c|}
\hline Variables & Test for Unit Root & Intercepts & Remarks \\
\hline TOT & Level & $0.446681^{* * *}$ & $\mathrm{I}(0)$ \\
\hline OILPCHA & Level & $0.214596^{* * *}$ & $\mathrm{I}(0)$ \\
\hline GDPGR & Level & $0.222946^{* * *}$ & $\mathrm{I}(0)$ \\
\hline INFLATION & Level & $0.130048^{* * *}$ & $\mathrm{I}(0)$ \\
\hline \multicolumn{4}{|c|}{ Critical Value } \\
\hline & $1 \%$ & 0.739000 & 0.463000 \\
\hline & $5 \%$ & 0.347000 & \\
\hline & $10 \%$ & ${ }^{*} \%$ & indicates stationary at $5 \%{ }^{*}$ indicates stationary at $10 \%$.
\end{tabular}

Table: 5. OLS Results for Nigeria.

\begin{tabular}{|c|c|c|c|c|c|}
\hline \multicolumn{6}{|c|}{ Dependent Variable: TOT } \\
\hline \multicolumn{2}{|c|}{ Regressors } & Coefficient & Std. Error & t-Statistic & Prob. \\
\hline \multicolumn{2}{|c|}{ INFLATION } & 0.000845 & 0.000738 & 1.145213 & 0.2604 \\
\hline \multicolumn{2}{|c|}{ GDPGR } & $0.025507^{* * *}$ & 0.004954 & 5.148772 & 0.0000 \\
\hline \multicolumn{2}{|c|}{ OILPCHA } & $0.003610^{* * *}$ & 0.000919 & 3.928772 & 0.0004 \\
\hline \multicolumn{2}{|c|}{$\mathrm{C}$} & $0.581955^{* * *}$ & 0.035520 & 16.38401 & 0.0000 \\
\hline \multicolumn{2}{|c|}{ R-squared } & 0.662650 & & & \\
\hline \multicolumn{2}{|c|}{ Durbin-Watson stat } & 1.672454 & & & \\
\hline \multicolumn{2}{|c|}{ F-statistic } & $21.60706^{* * *}$ & & & \\
\hline \multicolumn{2}{|c|}{ Prob(F-statistic) } & 0.000000 & & & \\
\hline \multicolumn{6}{|c|}{ Residual Diagnostics } \\
\hline \multicolumn{2}{|c|}{ Jarque-Bera } & 1.612048 & & & \\
\hline \multicolumn{2}{|c|}{ Prob } & 0.446630 & & & \\
\hline \multicolumn{6}{|c|}{ Breusch-Godfrey Serial Correlation LM Test } \\
\hline \multicolumn{2}{|c|}{ F-statistic } & 0.307905 & & & \\
\hline \multicolumn{2}{|c|}{ Prob. F(2,31) } & 0.7372 & & & \\
\hline \multicolumn{6}{|c|}{ Heteroskedasticity Test: Breusch-Pagan-Godfrey } \\
\hline F-statistic & & 540 & & & \\
\hline Prob. $\mathrm{F}(3,33)$ & & & & & \\
\hline
\end{tabular}

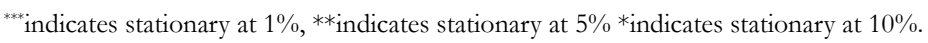


ries properties of each series. This was done with ADF unit root test and Kwiatkowski-Phillips-Schmidt-Shin test statistic (KPSS). The results are presented first for Nigeria's case and then for Angola's case.

\section{ADF Unit Root Test Results On Variables In Nigeria Case}

Table 1 shows the ADF unit root test for the variables in the model for Nigeria case. The test was done under the assumption that there is intercept in the series. The assumption of ADF is that the series have unit root. This is either rejected or accepted depending on whether the value of the t-Statistic is higher than the critical values at each level of significance. As shown in Table 1 , the value of $\mathrm{t}$-Statistic in the case of TOT is lower than the critical values at $1 \%$, but it is greater than the critical value at $5 \%$. Similarly, the probability is significant at $5 \%$ level of significance. This shows that though we do not reject the null hypothesis at $1 \%$ level of significance, but we reject the null hypothesis at $5 \%$ level. This shows that term of trade variable is stationary at level. The result for OILPCHA, GDPGR and INFLATION are significant at $1 \%$ level. This shows that all the series are stationary at level.

Source: Authors' computation using E-view.

\section{KPSS Unit Root Test Results On Variables In Nigeria Case}

The result of the ADF unit root test was confirmed with the KPSS unit root test. The KPSS hypothesis is that there is no unit root in the series. It is the opposite of the ADF unit root test. The KPSS statistic was less than the asymptotic critical values at each level of significance in the case of TOT. This is similar with the results of OILPCHA and GDPGR. INFLATION is also significant at $1 \%$ and $5 \%$ levels of significances. This confirms the results of the ADF unit root test, and it shows that all the series are $\mathrm{I}(0)$.
Source: Authors' computation using E-view.

\section{Unit Root Test Results On Variables In Angola Case}

\section{ADF Unit Root Tests}

The variables used for the relationship between term of trade and change in oil price were also subjected to unit root test using both ADF and KPSS unit root tests. Table 3 shows that the t-statistics value for TOT is higher than the critical values at $5 \%$ level, that of oil price change is higher than the critical values at $1 \%$ level, GDP growth rate is higher at 5\% level, while Inflation is higher than the critical vale at $1 \%$ level of significance. This shows that the null hypothesis can be rejected at $5 \%$ level of significance for all the variables, showing that they do not have unit roots.

Source: Authors' computation using E-view.

\section{KPSS Unit Root Tests}

Similarly, the ADF results were confirmed by the KPSS unit root test. The KPSS statistic for TOT is higher than the asymptotic critical values at $1 \%$ and $5 \%$ levels. This shows that null hypothesis cannot be rejected, and thus confirm that the variables is stationary. The result is not different in the cases of oil price change, GDP growth rate, and inflation which are all stationary at $1 \%$ level of significance.

Source: Authors' computation using E-view.

Given the findings of the ADF and KPSS unit root tests, the regression is best done using ordinary least square method. The result is first presented for Nigeria and then for Angola.

Table 6. OLS Results for Angola.

\begin{tabular}{|c|c|c|c|c|}
\hline \multicolumn{5}{|c|}{ Dependent Variable: TOT } \\
\hline Regressors & Coefficient & Std. Error & t-Statistic & Prob. \\
\hline INFLATION & $-5.80 \mathrm{E}-6$ & $2.48 \mathrm{E}-5$ & -0.233618 & 0.8168 \\
\hline GDPGR & 0.003041 & 0.003360 & 0.905115 & 0.3724 \\
\hline OILPCHA & $0.004359 * * *$ & 0.000884 & 4.928532 & 0.0000 \\
\hline $\mathrm{C}$ & $0.361296^{* * *}$ & 0.084230 & 4.289403 & 0.0002 \\
\hline R-squared & 0.692754 & & & \\
\hline Durbin-Watson stat & 2.150832 & & & \\
\hline F-statistic & $17.47408^{* * *}$ & & & \\
\hline Prob(F-statistic) & 0.000000 & & & \\
\hline \multicolumn{5}{|c|}{ Residual Diagnostics } \\
\hline Jarque-Bera & 0.897728 & & & \\
\hline Prob & 0.638353 & & & \\
\hline \multicolumn{5}{|c|}{ Breusch-Godfrey Serial Correlation LM Test } \\
\hline F-statistic & 0.130089 & & & \\
\hline Prob. $\mathrm{F}(2,31)$ & 0.8785 & & & \\
\hline \multicolumn{5}{|c|}{ Heteroskedasticity Test: Breusch-Pagan-Godfrey } \\
\hline F-statistic & 0.423737 & & & \\
\hline Prob. F(3,33) & 0.7903 & & & \\
\hline
\end{tabular}




\section{Discussion of Results for Nigeria}

Table 5 shows that change in oil price is significant in influencing the term of trade in Nigeria. Specifically, a positive relationship exists between change in oil price and term of trade. An increase of $1 \%$ in oil price will cause improvement of $0.003 \%$ in term of trade. This result is consistent with the postulates of theory since Nigeria is an oil exporting country. The result also indicates that increase in domestic market, proxied by the growth rate of GDP is also significant in influencing term of trade in Nigeria. As the domestic markets grows by $1 \%$, term of trade improves by $0.02 \%$. However, inflation is not significant in influencing term of trade.

The R-squared shows that $66 \%$ of the movement in TOT is explained in the model, while DW shows that there is autocorrelation. The significance of the F-statistic shows that all the overall significance of all the independent variables in the model.

Testing the Diagnostics test of the residuals, the result shows that the assumption of the OLS are satisfied as the Jarque Berra test there the residuals are normally distributed, Breusch-Godfrey Serial Correlation LM Test shows that there is no problem of serial correlation in the model. Similarly, Breusch-Pagan-Godfrey Heteroskedasticity Test shows that the model does not suffer from heteroskedasticity problem.

\section{Source: Authors' computation using E-view.}

\section{Discussion Of Results For Angola}

Table 6 shows the regression results for Angola. It shows that change in oil price is significant in influencing movement in term of trade in the country. Specifically, a $1 \%$ positive change in oil price brings $0.004 \%$ improvement in term of trade in Angola. The result is also consistent with what the theory says since Angola is also an oil exporting country. However, other variables such as inflation, domestic market are not significant in influencing term of trade in the country.

The R-squared shows that $69 \%$ of the movement in TOT is explained in the model, while DW is 2.1 , showing that there is auto correlation.

The significance of the F-statistic shows that all the overall significance of all the independent variables in the model at $1 \%$ level of significance. Testing the Diagnostics test of the residuals, the result shows that the assumption of the OLS are satisfied as the Jarque Berra test there the residuals are normally distributed, Breusch-Godfrey Serial Correlation LM Test shows that there is no problem of serial correlation in the model. Similarly, BreuschPagan-Godfrey Heteroskedasticity Test shows that the model does not suffer from heteroskedasticity problem.

\section{Source: Authors' computation using E-view.}

\section{Comparing The Effect Of Oil Price Change On Term Of Trade Between Nigeria and Angola}

The results indicate that positive change in oil price leads to increase in term of trade in both countries. This means that an increase in oil price leads to improvement in term of trade of each country. The result is however minute, meaning that for oil price to have much effects on term of trade of the two countries, the change must be of great magnitude. Also, the effect of oil price is felt more on the term of trade in Angola than it is in Nigeria.

\section{Summary and Conclusion}

The study is a comparative study of the effects of crude oil price changes on term of trade in Nigeria and Angola. Based on the findings of this study, it is concluded that crude oil price plays important role in affecting the term of trade of oil exporting countries which are also refined oil importers. It concludes that the effect is positive. As crude oil price increases, exports values increase much more than the increases in price of refined oil imports. However, while the effect is positive, it is very minute. It is 0.003 for Nigeria, while it is 0.004 for Angola. This shows that for oil price to have much effects on term of trade of the two countries, the change must be of great magnitude.

Given the results of this study, it is important that efforts should be made to reduce the refined oil imports into the countries. This will help reduce pressures on the countries' term of trade. This can be done by establishing crude oil refineries in each country. Also, it was shown in this study that domestic market improves term of trade in Nigeria, though it is insignificant in the case of Angola. Efforts should therefore be made to increase the non-oil sector exports of the economies to reduce the pressure on the oil sectors. This will help to improve the term of trade of the countries.

\section{References}

[1]. AfDB OE. African economic outlook 2016: sustainable cities and structural transformation. African development bank, organization for economic cooperation and development. United Nations Development Programme Tunis. 2016.

[2]. Angola Ministério das Finanças (2016). Relatório de Fundamentação. Proposta de OrçamentoGeral do Estado de 2017.

[3]. Backus DK, Crucini MJ. Oil prices and the terms of trade. Journal of international Economics. 2000 Feb 1;50(1):185-213.

[4]. Blattman C, Hwang J, Williamson JG. The terms of trade and economic growth in the periphery 1870-1938. National Bureau of Economic Research; 2003 Sep 1.

[5]. Blattman C, Hwang J, Williamson JG. Winners and losers in the commodity lottery: The impact of terms of trade growth and volatility in the Periphery 1870-1939. Journal of Development economics. 2007 Jan 1;82(1):156-79.

[6]. Bleaney M, Greenaway D. The impact of terms of trade and real exchange rate volatility on investment and growth in sub-Saharan Africa. Journal of development Economics. 2001 Aug 1;65(2):491-500.

[7]. Central Bank of Nigeria, Central Bank 2016 Statistical Bulleting, Abuja 2016.

[8]. Central Bank of Nigeria, Central Bank 2016 Statistical Bulleting, Abuja 2017.

[9]. Dibooğlu S, Aleisa E. Oil prices, terms of trade shocks, and macroeconomic fluctuations in Saudi Arabia. Contemporary Economic Policy. 2004 Jan;22(1):50-62.

[10]. Federal Reserve Bank of St. Louis database (2017).

[11]. Fosu AK. Terms of trade and growth of resource economies: A tale of two countries. WIDER Working Paper; 2011.

[12]. Grimes A. A smooth ride: Terms of trade, volatility and GDP growth. Journal of Asian Economics. 2006 Oct 1;17(4):583-600.

[13]. Husain MA, Arezki MR, Breuer MP, Haksar MV, Helbling MT, Medas MP, Sommer et al. Global implications of lower oil prices. International Monetary Fund; 2015 Jul 14.

[14]. Fund IM. World economic outlook database. World Econ Finance Survey. 2017 Aug.

[15]. Nigerian Bureau of Statistics, Abuja 2015.

[16]. Jawaid ST, Waheed A. Effects of terms of trade and its volatility on economic 
growth: a cross country empirical investigation. Transition Studies Review. 2011 Dec 1;18(2):217-29.

[17]. Mendoza EG. Terms-of-trade uncertainty and economic growth. Journal of Development Economics. 1997 Dec 1;54(2):323-56

[18]. Mirfacihi A. Oil Prices and Terms of Trade: A comparison between Saudi Arabia and the United States.

[19]. Session F. United Nations Conference on Trade and Development.
[20]. United Nation Economic Commission for Africa. Angola Country Profile. Addis Ababa, Ethiopia 2017.

[21]. Wong HT. Terms of trade and economic growth in Japan and Korea: an empirical analysis. Empirical Economics. 2010 Feb;38(1):139-58.

[22]. World Bank Development Indicator 2017. 